\title{
Urbanisoituva yliopistokampus informaalin oppimisen mahdollistajana
}

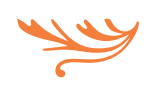

Tiivistämällä kaupunkirakennetta, monipuolistamalla kampusalueen käyttöä ja perustamalla puistomaisia viheralueita voidaan elävöittää kaupunkien reunamilla sijaitsevia kampusalueita. Samalla vahvistetaan kampuksen

käyttäjien välistä vapaamuotoista vuorovaikutusta.

\section{$\mathbf{y}$} YLIOPISTOT OVAT OSA kansainvälistä tiedeyhteisöä mutta samalla erittäin vahvoja toimijoita maakunnissaan ja kaupungeissaan. Jo sana 'yliopistokaupunki' paljastaa, että yliopistot ovat tiukasti sidoksissa sijaintikaupunkiinsa. Yliopistokampus muodostaa kokonaisuuden, johon kuuluvat rakennusten ja ulkotilojen lisäksi niiden käyttäjät ja toiminnot. Jokaisella Suomen yliopistolla on yksi tai useita kampuksia, joiden suhde yhdyskuntarakenteeseen vaihtelee huomattavasti kaupungeittain. Useimmissa yliopistokaupungeissa kampus ja sen rakennukset ovat kuitenkin tärkeä osa kaupunkikuvaa ja -rakennetta.

Delftin teknillisen yliopiston apulaisprofessori Alexandra den Heijer luokittelee väitöskirjassaan
(2011, 53) yliopistokampukset kolmeen tyyppiin: 1) kaupungin ulkopuolella sijaitsevaan greenfieldkampukseen, 'metsäkampukseen' tai halventavasti 'korpikampukseen, 2) kaupungin sisäpuoliseen rajattuun kampukseen ja 3) kaupunkirakenteeseen integroituneeseen, useaan paikkaan hajautuneeseen kampukseen. Hän esittää lähinnä Alankomaiden yliopistojen historialliseen kehitykseen tukeutuen, että 1900-luvun ensimmäisiin vuosikymmeniin asti yliopistot olivat täysin integroituneita kaupunkirakenteeseen. Tämän jälkeen 1950-70-luvuilla yliopistot rakentuivat kaupunkien reuna-alueille. Nykytilanteeseen päädyttiin, kun kampusalueet jäivät kaupunkien sisään näiden laajentuessa. (Mt., 61.) 


\section{KAMPUSTEN SUUNNITTELU}

\section{TUKEE YLIOPISTON \\ YDINTEHT $\ddot{A} V \ddot{A} \ddot{A}$ JA}

SITOUTUMISTA YHTEISKUNTAAN.

Suomessa yliopistokampusten kehitys on ollut samansuuntainen. Vanhimmat yliopistot Helsingissä ja Turussa sijaitsivat alun perin keskusta-alueella. Toisen maailmansodan jälkeisinä vuosikymmeninä, etenkin 1960-70-luvuilla, perustettiin muun muassa aluepoliittisista syistä lukuisia yliopistoja maan eri osiin. Keskeistä sijaintia ei enää pidetty tarpeellisena, vaan yliopisto pyrittiin sijoittamaan kansainvälisiä trendejä seuraten mahdollisimman yhtenäiselle kampusalueelle kaupunkikeskustojen ulkopuolelle, jossa suuria maa-alueita oli helpommin hankittavissa. 1960-luvun loppupuolelta lähtien yliopistojen suunnitteluun tuli aiempaa enemmän mukaan ympäröivän yhdyskunnan suunnittelu, joka kristallisoitui ajatuksena yliopiston ympärille rakentuvasta tytärkaupungista tai tavanomaista lähiötä suuremmasta keskuksesta. (Vuorinen 2011, 12-16.)

Yliopistokampusten vallitseva suunnitteluparadigma korostaa yliopistojen ydintehtävien tukemista ja sitoutumista ympäröivään yhteiskuntaan. Ideaalina on kaupunkiin ja yhteiskuntaan integroituva yliopisto ja kampus, joka muodostaa jonkinlaisen ideologisen vastakohdan toisen maailmansodan jälkeisinä vuosikymmeninä tavoitellulle muusta kaupunkirakenteesta irralliselle ja omavaraiselle koulutus- ja tiedeyhteisölle.

Integroitumisen perusteluina käytetään muun muassa eri toimintojen synergiaa ja yliopistojen kilpailukyvyn paranemista. Suomen suurin kampuskehittäjä, Suomen Yliopistokiinteistöt Oy ilmaisee sen verkkosivuillaan (sykoy.fi 2014) seuraavasti: "Saatamme yhteen eri toimijoita ja synnytämme synergiaa. Ohjaamalla tiloja tuottavaan toimintaan ja synnyttämällä uusia yhteistyömalleja, olemme turvaamassa yliopistojen tulevaisuutta ja lisäämässä niiden kilpailukykyä ja houkuttelevuutta." Vastaavia tavoitteita esittää myös Aalto-yliopistokiinteistöt Oy (aaltocre.fi 2016). Suomen Yliopistokiinteistöt Oy omistaa tutkimiemme kampusten kiinteistöt ja vastaa niiden rakennuttamisesta, kehittämisestä ja vuokraamisesta. Suurin osa yhtiön osakkeista on yliopistojen hallinnassa.

Yliopistojen tai niiden kampusten kehitys ei ole millään muotoa pysähtynyt, vaan odotettavissa on suuria muutoksia muun muassa globalisaation, julkisen rahoituksen vähenemisen ja digitalisaation vuoksi (Rytkönen 2016, 25, 39). Lisäksi opiskelijat, opettajat, tutkijat, kampusten lukuisat muut toimijat ja kampusten sijaintikaupungit asettavat monimuotoisia toiveita ja vaatimuksia kampusten toiminnalle. Keskustakampusten muutospaineet ovat lähtökohtaisesti suurempia kuin muiden kampusten, sillä niiden sijainti herättää suuria taloudellisia ja maankäytöllisiä intressejä.

Informaalin oppimisen näkökulmasta tutkimamme kampukset näyttäytyvät vapaamuotoisen, oppijalähtöisen ja erilaisissa yhteisöllisissä arjen vuorovuorovaikutustilanteissa toteutuvan oppimisen tapahtumapaikkoina (esim. Marsick \& Watson 2001). Emme siis tutki informaalia oppimista sinänsä vaan yliopistokampusta sen mahdollistajana ja tärkeänä kontekstina.

Keskitymme kolmeen empiirisessä tutkimusaineistossamme esiin nousseeseen yliopistokampuksen elävöittämisen teemaan: 1) kampusalueen rakenteelliseen tiivistämiseen, 2) sen toimintojen monipuolistamiseen sekä 3) puistomaisiin viheralueisiin. Elävöittämisellä tarkoitamme kampuksen käyttötapojen ja ulkotilojen monipuolistamista ja sen toimintojen laajentamista iltoihin, viikonloppuihin ja loma-aikoihin. Tutkimuskysymyksemme on, miten urbanisoituminen ilmenee keskustan reuna-alueiden yliopistokampuksilla ja luo samalla edellytyksiä informaalille oppimiselle.

\section{TUTKIMUSAINEISTO JA -MENETELMÄT}

Tulkintamme nojaavat erityisesti kampusympäristön suunnittelua ja elävöittämistä käsittelevään tutkimuskirjallisuuteen, ja mielenkiintomme kohdistuu kysymykseen yliopistokampuksesta informaalin oppimisen kontekstina. Hyödynnämme tutkimuksessa 


\section{URBAANIN K ̈̈SITE SISÄLT $\ddot{A} \ddot{A}$}

\section{OLETUKSEN KAUPUNKIMAISESTA}

\section{EL $\ddot{A M A ̈ N T A V A S T A . ~}$}

aineisto- ja menetelmätriangulaatiota eli yhdistämme useita aineistotyyppejä ja tutkimustapoja. Lähestymme aihetta sekä "ylhäältä alas" kaupunkirakenteellisin tarkasteluin että "alhaalta ylös" kampuksilla tehtyjen haastattelujen ja havainnoinnin avulla. Tutkimuksen empiirinen aineisto on vuodelta 2016 ja koskee Joensuun, Jyväskylän, Tampereen, Turun ja Vaasan yliopistojen keskustakampuksia.

Tutkimuksemme tausta-aineistoon kuuluu yliopistokampusten analyysi, jossa on hyödynnetty havainnoivan tutkimuksen lisäksi kampusalueiden suunnitelmia ja kartta-aineistoja sekä kampusalueita käsitteleviä strategioita, visioita, historiallisia dokumentteja ja muita kirjallisia lähteitä. Analyysin avulla on muodostettu käsitys kampuksia ympäröivän kaupunkirakenteen historiallisesta kehityksestä sekä tavoista, joilla kampukset nykyään kytkeytyvät siihen (kuvat 1-5).

Taustatutkimuksen 25 temaattista opiskelijahaastattelua tehtiin arkipäivinä. Haastatteluja ei sovittu etukäteen eikä niihin pyritty keräämään mitään tietyn profiilin ihmisjoukkoa, vaan niiden avulla haluttiin tarkoituksellisesti saada otos haastatteluhetkellä sattumalta kampusalueella olevista ihmisistä. Haastatteluaineisto kattaa viisi henkilöä kultakin tutkimaltamme yliopistokampukselta, joten pitkälle meneviä kvantitatiivisia päätelmiä ei sen perusteella ole syytä tehdä. Haastatellut olivat ennakko-odotusten mukaisesti noin 20-30-vuotiaita opiskelijoita, poikkeuksena yksi noin 50-vuotias opiskelija. Naisia haastatelluista oli 13; Turussa haastatelluista vain yksi oli mies ja Vaasassa vain yksi nainen.

Haastattelut toteutettiin etukäteen laadittujen teemoitettujen kysymysten pohjalta. Näin pyrittiin hankkimaan mahdollisimman kattava kuva haastateltavien yliopistokampusta koskevasta kokemusmaailmasta. Teemat perustuivat yhdysvaltalaisen kaupunkisuunnittelijan Jeff Speckin (2012) muodostamaan malliin, johon kuuluu neljä käveltävyyden laatu-ulottuvuutta: hyödyllisyys, turvallisuus, mukavuus ja mielenkiintoisuus. Käveltävyys kuvaa sitä laajuutta, jolla rakennettu ympäristö tukee ja kannustaa kävelemistä (Southworth 2005, 247-248). Kysymykset laadittiin tarkoituksellisesti neutraaleiksi, jotta ne eivät ohjaisi vastauksia. Analysoinnin helpottamiseksi haastattelut litteroitiin sanatarkasti, minkä jälkeen niitä tarkasteltiin tulkitsevan sisällönanalyysin keinoin.

\section{URBANISOITUVA YLIOPISTOKAMPUS KAUPUNGIN YDINKESKUSTAN REUNALLA}

Urbaanin käsite sisältää oletuksen kaupunkimaisesta elämäntavasta, jossa vilkas kaupunkielämä ja siihen kuuluvat ennakoimattomatkin kohtaamiset synnyttävät innovaatioita ympäristön toimintojen, yhdyskuntarakenteen ja väestön heterogeenisyyden myötävaikutuksella. Yliopistokampusta ei kuitenkaan voi määritellä urbaaniksi vain sen sijainnin, iän tai syntytavan, opiskelijapopulaation tai akateemisten ohjelmien mukaan vaan ennen muuta sen kautta, miten yliopisto näkee itsensä suhteessa ympäristöönsä ja sijaintiyhteisöönsä (Elliot 1994, 22-23; McNamara Horvat \& Shaw 1999, 103, 106). Näin ollen yliopistokampuksen urbanisoituminen ei ole vääjäämätön prosessi vaan pitkälti institutionaalinen valinta, joka ilmentää yliopiston halua olla urbaani. Kampusta ei silti voi täysin erottaa ympäröivästä kaupungista, vaikka yliopisto niin haluaisikin. Yhdysvaltalaisen kampuskehittäjän Peggy Gordon Elliottin sanoin (1994, 23; suomennos tekijöiden): "Urbaanit korkeakoulut ja yliopistot kuuluvat erottamattomasti suurkaupunkimiljööseen. Ne eivät ole vain kaupungissa tai lähellä kaupunkia; ne ovat kaupunkia.”

Yliopistokampuksella on periaatteessa kaksi mahdollisuutta urbanisoitua. Ensinnäkin se voi laajentaa toimintojaan alkuperäisten rajojensa ulkopuolelle ja sulautua kaupunkiin. Tällöin avautuu mahdollisuuksia yhteistyöhön muiden toimijoiden kanssa, mutta integroituminen voi merkitä kampusidentiteetin katoamista. Toiseksi kaupunkimaisia toimintoja voidaan tuoda kampuksen sisälle, jolloin sen identiteetti omana yksikkönään on helpompi säilyttää. (Poutanen, Peltoniemi \& Pihlajarinne 2015, 75.) 
Artikkelissamme ei ole mahdollista tarkastella identiteetin muodostumisen eri osatekijöitä, joten tyydymme toteamaan, että kampuksilla on vähitellen rakentunut, ajassa muuntuva yhteisöllinen identiteetti. Yliopistokampus on lähtökohtaisesti yhteisöllinen ympäristö; toimiihan yliopisto-sanan kantana useissa indoeurooppalaisissa kielissä latinan universitas, joka alun perin tarkoitti opettajien ja opiskelijoiden yhteisöä. Yhteisöllisyyden teema on löydettävissä jossakin muodossa lähes kaikkien suomalaisten yliopistojen strategioista ja rakennettuina fyysisinä muotoina useimmilta kampusalueilta. Muuallakin kuin Suomessa yhteisöllisyys on usein ollut yliopistokampusten suunnittelun tavoitteena, mutta valmiissa kampusympäristössä sen toteutumista voi olla vaikea hahmottaa (Temple 2008, 231-232).

Jokaisella tutkimuksessamme mukana olleella yliopistokampuksella on toisistaan poikkeava syntytapa, mutta niitä yhdistää sijainti keskustan ruutukaava-alueen läheisyydessä. Jyväskylän yliopistokampuksen historia on pisin: se ulottuu vuonna 1863 perustettuun opettajankoulutusseminaariin asti. Arkkitehti Alvar Aallon suunnittelema osa lähti rakentumaan vuonna 1951. Myöhemmin kampusalue on levinnyt kohti kaakkoa Mattilanniemen ja Ylistön alueelle. Jyväskylässä puhutaan kolmesta kampuksesta, mutta läheisyytensä ja hyvien keskinäisten yhteyksiensä ansiosta ne muodostavat yhden kokonaisuuden. Åbo Akademin kampus alkoi kehittyä Turun Yliopistonmäelle vuonna 1918. Samalle alueelle valmistuivat vuonna 1954 arkkitehti Aarne Ervin suunnittelemat Turun yliopiston ensimmäiset rakennukset. Tampereen yliopiston kampusalue sai alkunsa päärakennuksen valmistuessa vuonna 1960, Joensuun kampus 1970-luvun puolivälissä ja Vaasan kampus vuonna 1994.

Vuosikymmenten mittaan kaikki viisi kaupunkia ovat kasvaneet ja niiden sisäinen dynamiikka on muuttunut. Alun perin kaupungin keskusta-alueen liepeille perustetut kampukset ovat nykyään kaupunkirakenteellisesti keskeisellä paikalla. Joensuun kampusalueen läpi kulkeva Kuopiontie on oleellisesti vaikuttanut kampusalueen muotoutumiseen. Yliopistorakennukset sijaitsevat lähellä toisiaan, ja käyttäjien haastattelujen perusteella ne ovat hyvin saavutettavissa. Jyväskylän metsämäinen kampusalue on rakentunut Seminaarinmäen päälle noin kilometrin päähän ydinkeskustan kävelykadusta. Tutkimistamme kampusalueista Tampere sijaitsee lähinnä kaupungin toiminnallista ydintä. Kampusalue näkyy saavuttaessa kaupunkiin autolla tai junalla etelästä. Uusia mahdollisuuksia sen kehittämiselle tarjoavat kaupungin keskustaan suunnitellut suuret rakennusprojektit, kuten Tampere-talon viereen kaavailtu uusi hotelli sekä junaradan päälle rakennettava Kansi ja Areena, johon sisältyy monitoimiareenan ja kasinon lisäksi muun muassa asuntoja, toimistoja, liikkeitä ja julkisia ulkotiloja.

Turun yliopistokampus sijaitsee kaupungin keskustan tuntumassa Aurajoen itäpuolella. Kampusalue ulottuu Tuomiokirkolta Kupittaan rautatieasemalle. Kampuksen urbanisoituminen on tutkituista kampuksista pisimmällä. Aluetta leimaa monimuotoinen rakennetun ympäristön historiallinen kerrostuneisuus: kampusrakennusten keskellä on asutusta ja muita toimintoja. Vaasan yliopiston merenrantamaisemassa sijaitseva tiivis kampus on alueena eheä, esteettinen ja yhtenäinen. Kampuksella on myös opiskelija-asuntoja.

Kaupunkirakenteen ja kampusalueen lomittumisen aste on tutkittujen esimerkkien osalta lähes suoraan verrannollinen yliopistokampuksen ikään. Uusimmilla kampusalueilla yliopistorakennuksille varattu maa-alue on vielä riittänyt laajentumistarpeisiin, vanhemmilla on vuosikymmenten kuluessa syntynyt tarve levittäytyä alkuperäisen kampusalueen ulkopuolelle. Jyväskylän ja Turun yliopistokampusalue (kuvat 1-5) ovat jo selvästi alkaneet lomittua ympäröivään kaupunkirakenteeseen. Sen sijaan Joensuun ja Vaasan kampukset ovat yhä täysin omia kokonaisuuksiaan. Tampereen yliopiston keskustakampus erottuu omana yksikkönään muusta kaupunkirakenteesta, mutta yliopiston uusin Linna-niminen rakennus sijaitsee jo viereisen Tullin alueen korttelin sisällä.

Yksikään tutkimistamme kampuksista ei vielä ole integroitunut kaupunkikeskustaan samalla tavoin kuin vaikkapa Helsingin yliopiston keskustakampus, jonka rakennuksia kadulla kulkiessa ei välttämättä erota muusta kaupunkiarkkitehtuurista, vaikka ne sijaitsevat ydinkeskustassa varsin pienellä alueella. 

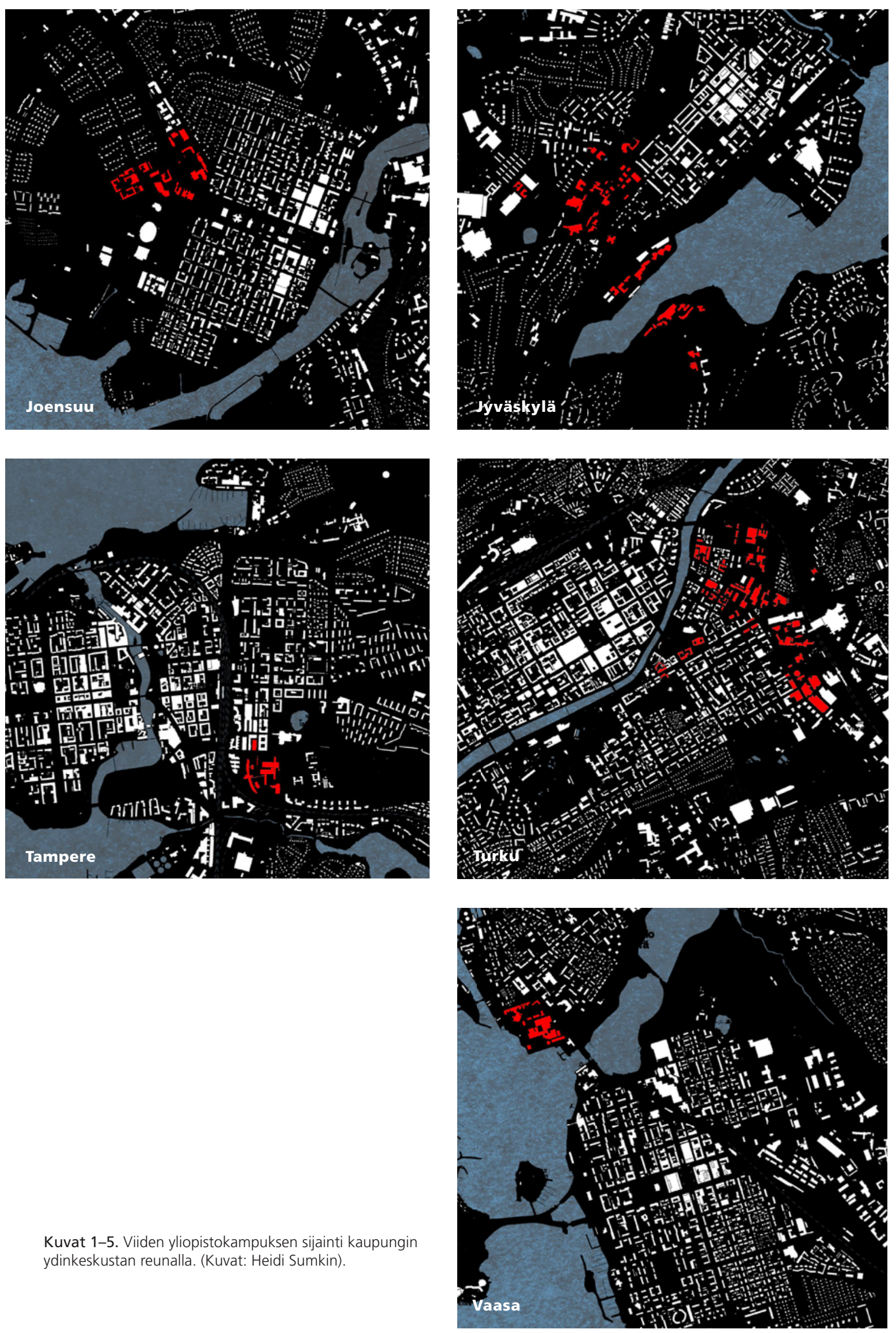

Kuvat 1-5. Viiden yliopistokampuksen sijainti kaupungin ydinkeskustan reunalla. (Kuvat: Heidi Sumkin). 
Useat todella vanhat yliopistot ovat täysin sulautuneet muuhun kaupunkirakenteeseen. Esimerkiksi Oxfordin yliopisto sijaitsee kymmenissä yksittäisissä rakennuksissa muiden kaupunkitoimintojen lomassa yli neliökilometrin alueella.

Jokainen tutkimamme yliopistokampus on toiminnallisesti varsin yksipuolinen verrattuna viereisen kaupunkikeskustan monimuotoisuuteen. $\mathrm{Ne}$ eivät siten ole toiminnallisesti urbaania tilaa, mutta niillä on potentiaalia muuttua sellaiseksi keskeisen sijaintinsa ja kaupunkien kasvuun liittyvien inhimillisten ja taloudellisten resurssien lisääntymisen ansiosta (West 2017, esim. 275-301). Kampusten kaupungistumisprosessi, urbanisoituminen, on tässä mielessä vasta aluillaan. Käytämme tästä kehitysvaiheesta nimitystä 'urbanisoituva yliopistokampus' ja väitämme, että tällainen kampustyyppi on ainakin Suomessa yleinen, eikä sitä ole riittävän selkeästi tunnistettu aiemmassa kampustutkimuksessa.

\section{YHTEISKUNNALLISET ODOTUKSET JA INFORMAALI OPPIMINEN}

Yliopistojen opetusta, tutkimusta ja yhteiskunnallista vaikuttamista koskevat odotukset vaihtelevat kulloistenkin ihanteiden ja poliittisten tavoitteiden mukaisesti. Kymmenen viime vuoden aikana on koettu tarvetta muun muassa kansainvälistymisen ja kilpailukyvyn lisäämiseen (HE 7/2009), työelämään siirtymisen nopeuttamiseen ja osaamiskeskittymien luomiseen (VNA 322/2016) sekä joustavuuteen ja herkkään reagointikykyyn (Tirronen \& Kivistö 2009, 69). Kampusten hallinnoinnin muutos kohti asiakas- ja palvelukeskeisyyttä on osaltaan kasvattanut mielenkiintoa epämuodollista ja monialaista ryhmätyöskentelyä kohtaan (Rytkönen 2016, 38).

Erityisesti yhteiskunnallista vaikuttavuutta koskevien odotusten täyttämiseksi tarvitaan hyviä yhteistyötaitoja ja kykyä toimia erilaisissa ja yllättävissäkin vuorovaikutustilanteissa. Tällaisia sosiaalisia taitoja opetetaan sellaisenaan ani harvoin yliopistojen formaalin eli muodollisen ja strukturoidun oppimisen piirissä, mutta niitä voidaan edistää oppimistilanteissa, jotka edellyttävät ja edistävät vuorovaikutusta. Kun yhteiskunnallisia käytäntöjä pyritään tuomaan lähemmäksi oppijaa, on luontevaa käyttää informaalia oppimista hyödyntävää pedagogiikkaa, jonka on todettu vaikuttavan myönteisesti oppijan sitoutumiseen ja motivaatioon (Kumpulainen ym., 2010, 83).

Arizona State Universityn professorin Daniel Schugurenskyn (2000) mielestä informaali oppiminen on liian laaja käsite käytettäväksi analyyttisena kategoriana. Hän esittää sille kolme alakäsitettä: 1) itsenäinen oppiminen (tietoinen ja tarkoituksellinen), 2) oheisoppiminen (tietoinen, mutta ei tarkoituksellinen) ja 3) sosialisaatio (ei tietoinen eikä tarkoituksellinen).

University of Toronton kasvatussosiologian professori David Walker Livingstone (2001, 2-4) sen sijaan jakaa informaalin oppimisen neljään kategoriaan: 1) itseohjautuvaan oppimiseen, 2) kollektiiviseen oppimiseen, 3 ) informaaliin koulutukseen ja 4) informaaliin harjoitteluun. Ensimmäiset kaksi ovat oppijakeskeisiä ja jälkimäiset opettajakeskeisiä. 'Informaali koulutus' kuulostaa ristiriitaiselta, mutta Livingstone tarkoittaa termillä mentoroinnin kaltaista ohjausta spontaaneissa oppimistilanteissa (mt.).

Käytämme informaalin oppimisen käsitettä yleisluonteisesti, sillä sekä Schugurenskyn että Livingstonen kategoriat ilmenevät oppimistilanteissa yleensä toisiinsa limittyneinä, jolloin niitä on vaikea tai jopa mahdotonta erottaa. Alan kirjallisuuden perusteella informaalille oppimiselle on tiivistetty seuraavat piirteet (Callanan, Cervantes \& Loomis 2011): 1) se ei ole didaktiivista, 2) se on sosiaalisesti erittäin yhteistoiminnallista, 3 ) siihen on sulautettu merkityksellistä toimintaa, 4) se on lähtöisin oppijan mielenkiinnosta ja valinnasta ja 5) sitä ei arvioida ulkopuolelta. Kuudenneksi piirteeksi on syytä lisätä, että informaali oppiminen on luonteeltaan tilannesidonnaista (esim. Livingstone 2001), jolloin oppimisympäristö vaikuttaa ratkaisevasti sekä oppimistapoihin että opittuihin taitoihin ja tietoihin.

Informaaliin oppimiseen sisältyy paljon potentiaalia; kanadalaisen tutkimuksen mukaan aikuiset käyttävät siihen keskimäärin 15 tuntia viikossa, tosin eri ihmisten tuntimäärät vaihtelevat huomattavasti (mt., 15-16). Informaalin oppimisen ympäristö voi periaatteessa olla mikä tahansa muodollisen 
KAUPUNKI ON IHMISYHDYS-

\section{KUNTA, JOSSA MUUKALAISET \\ TODENN ̈̈KÖISESTI}

KOHTAAVAT.

koulutustilan ulkopuolella oleva paikka (Kumpulainen ym. 2010, 92). Yliopisto-opiskelijalle kampuksella sijaitsevat epämuodolliset tilat ja paikat ovat olennaisia, sillä hän kulkee niissä päivittäin. Tarve lisätä informaalia oppimista kampuksilla on tullut esille useissa aiemmissa tutkimuksissa (Ibrahim \& Fadzil 2013; Poutanen 2015, 376; Temple 2008, 238).

\section{YLIOPISTOKAMPUKSEN TIIVIYS INFORMAALIN OPPIMISEN MAHDOLLISUUKSIEN EDISTÄJÄNÄ}

Yhteistoiminnallisen informaalin oppimisen mahdollistamisessa kampuksilla on olennaista ihmisten "törmäyttäminen", sattumanvaraisten kohtaamisten järjestäminen toistensa ajatuksista potentiaalisesti hyötyville (Poutanen, Peltoniemi \& Pihlajarinne 2015, 76). Urbanisoituminen tukee törmäyttämisen tavoitetta, sillä urbaanin elämän keskeinen ulottuvuus on monimuotoinen sosiaalisuus (Ilmonen 2010, 21-23), ja kaupunkimaiseen ympäristöön kuuluvat olennaisena siinä liikkuvien ihmisten tapaamiset.

London School of Economicsin sosiologian professori Richard Sennettin jo klassikoksi muodostuneen määritelmän mukaan "kaupunki on ihmisyhdyskunta, jossa muukalaiset todennäköisesti kohtaavat" (Sennett 1977, 39; käännös tekijöiden). Yksi tärkeimpiä edellytyksiä kohtaamisille on riittävä tiiviys: samoissa paikoissa ja tiloissa on yhtä aikaa tarpeeksi ihmisiä ja toimintoja. Tämä on suomalaisten kampusten suunnittelussa nykyisin varsin hyvin sisäistetty. Esimerkiksi Lahden ammattikorkeakoulun kampuksen suunnittelussa on kehitetty konseptia, jossa kampuksen saavutettavuutta ja toimintaympäristöjen avautumista mahdollisimman monipuoliselle käyttäjäjoukolle on pohdittu koko kaupunginosan näkökulmasta (Hyökki, Kaikonen \& Nenonen 2015).
Kampusalueen tiiviyden kokemus nousi muita asioita voimakkaammin esiin, kun tutkimme, onko kampuksen käyttäjille muodostunut jaettujen merkitysten välityksellä niin sanottu aluetietoisuus (Paasi 1986). Se voi antaa tunteen siitä, millainen oma kampus on verrattuna muihin kampuksiin. Haastateltavat tunnistivat kampuksensa omaksi alueelliseksi kokonaisuudekseen, mutta haastatteluissa ei havaittu vahvaa kampukseen sitoutunutta omaleimaisuuden kokemusta. Kaikki haastateltavat miettivät jonkin aikaa vastaustaan kysymykseen, mikä heidän kampuksessaan oli erityistä ja mikä erotti sen muista Suomen kampuksista. Lopulta suurella osalla (36\%) vastaus oli samankaltainen: haastateltavat kokivat oman yliopistokampuksensa muita kampuksia kompaktimmaksi.

"No ehkä tää sijainti, et tää on tälleen korkeen mäen päallä, voi olla silleen omalaatuisempi. Sit ku lähtee tonne päin niin on se puutaloalue siinä välissä, joka on aika mielenkiintoinen ja tosi hieno. Mä olen Tampereelta kotoisin, siellä se on taas hajautettu niin ympäri kaupunkia eri toimipisteet, täällä tää alue on hyvin tiivis."

(H3, Turku, mies, noin 20 vuotta)

"No nämä, en tiedä miten muissa kampuksissa, tuntuu et kaikissa on erotettu kampukset toisistaan, niin tässä nämä kaikki on kuitenkin vierekkäin, nämä on ihan muutaman sadan metrin välein ja nämä on periaatteessa samassa kaupunginosassa, on helppo kulkea niiden väliä." (H15, Jyväskylä, nainen, noin 30 vuotta)

"No tässä on ainakin lähekkäin nämä, lääkis on vähän kauempana, mut muuten nämä on lähekkäin, et jos on luentoja eri rakennuksissa, niin ei ole pitkä matka siirtyä."

(H17, Tampere, nainen, noin 25 vuotta)

"No en oo ihan hirveesti noilla muilla kampuksilla käynyt, mut ainakin mitä oon kuullut, niin niillä ne eri rakennukset on erillään, saattaa olla ihan eri puolilla kaupunkia. Voisin kuvitella, et se on sellanen asia, joka on täällä tosi hyvin hoidettu." (H22, Joensuu, nainen, noin 20 vuotta) 
Oman kampuksen kompaktiutta korostava tiiviysharha tuli ilmi kaikilla kampuksilla, tosin Tampereen ja Vaasan osalta ei voi puhua harhasta, sillä niiden keskustojen kampusalueet ovat oikeasti kompakteja (kuvat 3 ja 5). Tiiviysharha voi johtua siitä, että toisten kaupunkien kampuksia ei tunneta hyvin, jolloin ne kuvitellaan isoiksi ja harvaan rakennetuiksi. Toisaalta oma kampus voi tuntua pieneltä juuri sen vuoksi, että se on tuttu ympäristö. Joka tapauksessa haastatellut kokivat kampusalueen kompaktiuden myönteisesti, ja heidän kommenttinsa tiiviydestä osoittivat, että kampusten eri toimintojen saavutettavuutta kävellen pidetään tärkeänä.

\section{TOIMINTOJEN MONIMUOTOISUUS JA INFORMAALI OPPIMINEN}

Kampuksen kokoa arvioidessaan opiskelijat tarkoittavat 'tiiviydellä' kampuksen rakennusten fyysistä läheisyyttä. Termillä on urbaaniuden näkökulmasta toinenkin ulottuvuus: toimintojen suhteellinen monimuotoisuus tietyllä alueella. Tutkimiltamme kampuksilta löytyi oppimis- ja tutkimustoimintojen lisäksi niihin liittyviä aputoimintoja, kuten ruokailu-, pysäköinti-ja odottelupaikkoja. Asumista niillä ei ollut ollenkaan tai se oli kohtuullisen vähäistä, ja niiltä puuttui monia palveluja ja vapaa-ajan toimintoja, joista etenkin harrastukset täyttävät suurimman osan informaalisen oppimistilanteen piirteistä. Kaikkien tarkasteltujen yliopistokampusten strategioissa, Jyväskylää lukuun ottamatta, kuitenkin tavoitellaan kampuksen tilojen ja alueiden käyttötarkoitusten sekoittamista ja monipuolistamista (sykoy.fi 2014), mikä lisää kampuksen käyttöä myös varsinaisen työajan ulkopuolella. Samoihin tavoitteisiin on pyritty Britanniassa jo 1960-luvulla ja Yhdysvalloissa 1970-luvulla (Temple 2008, 230-231).

Tiedusteltaessa, mitä kampusalueen pitäisi tarjota, jotta haastatellut tulisivat sinne muutenkin kuin opiskelua tai työtä varten, saatiin muun muassa seuraavat vastaukset:

"Baari, eikse ny sulkenu ovensa se Proffankellari täällä, et baari olis aika kiva. Sit, jos olis tyyliin joku koripallokenttä, joku mis vois kavereiden kanssa pelata jotain." (H5, Turku, nainen, noin 20 vuotta)
”Mielenkiintoinen kysymys, kyllä tääl voi viettää hyvin vapaa-aikaa, tääl on näitä paikkoja missä olla, mutta mä kyllä enemmän oon, et tänne tullaan, mä opiskelin ennen himassa ja se vähän kärsi siinä ku on erilaisii houkutuksia ja sitte mä oon aatellut et tää on puhtaasti, et tänne tullaan opiskeleen ja sit leimataan ittensä ulos ja lähdetään viettään vapaa-aikaa. Tää on opiskelu- ja työpaikka. (H8, Vaasa, mies, noin 30 vuotta)

Useat haastatellut todellakin suhtautuivat opintoihin työnä ja kampukseen työpaikkana, joka halutaan erottaa vapaa-ajasta. Tampereen ja Jyväskylän kampuksilla haastatelluista opiskelijoista yksikään ei kertonut viettävänsä vapaa-aikaansa kampuksella. Mikäli asenne osoittautuu yleiseksi, se voi rajoittaa kampuksen toimintojen monipuolistamista ja sen myötä urbanisoitumista. Haastatteluaineiston perusteella kampusten ja yliopistojen vetovoimaisuus näyttää opiskelijoiden näkökulmasta olevan sidoksissa ensisijaisesti tarjolla oleviin opintoihin ja niiden houkuttelevuuteen. Kampuksen palvelut tai mielenkiintoiset tilat ovat monelle opiskelijalle mukava lisä.

Asuntojen sijoittaminen kampusalueille on yksinkertainen tapa tiivistää kampuksen kaupunkirakennetta ja tuoda kampuksille ihmisiä varsinaisten työ- ja opiskeluaikojen ulkopuolellakin. Kysyttäessä haastatelluilta, voisivatko he kuvitella asuvansa kampusalueella, suuri osa suhtautui asiaan kielteisesti tai varauksellisesti, joskin toisenlaisiakin mielipiteitä esiintyi.

"En kyllä, en kyllä hakis niitä asuntoja." (H14, Jyväskylä, nainen, noin 30 vuotta)

"Paha kysymys. Mä olen aikoinani asunut TY:n ihan vieressä Tekniikkatorneilla, mun kellarinovesta pääsi suoraan sisään, siin oli ihan mukava asua. Mut, jos asuintalo olis täs ihan keskellä, niin en välttämättä asuis." (H20, Tampere, mies, noin 30 vuotta)

"Henkilökohtaisesti en ite, mutta kyllähän se monelle muulle helpottais. Kyllähän ne on vissiin rakentamassa tähän viereen, tohon alikulkutunnelin toiselle puolelle mistä lähtee noi ammattikoulurakennukset pois. Ite en asuis, oon tottunut asumaan silleen ettei ihan tässä suoraan alueella, mutta kyllä se varmaan jollekkin olis helppoo." (H24, Joensuu, mies, noin 30 vuotta) 


\section{PuistomaiseT VIHERALUEET}

\section{LIS $\ddot{A} \mathrm{~A} \ddot{\mathrm{A} T}$ KAMPUSTEN}

VIIHTYISYYTT ̈̈.

”Kyllä itse asiassa voisin, toki viel tääl ei oo samanlaista kulttuuria ku Yhdysvalloissa missä asutaan ihan kampusalueella." (H9, Vaasa, mies, noin 25 vuotta)

Kampusalueelle on kuitenkin mahdollista rakentaa asuntoja ja palveluja muillekin kuin opiskelijoille. Alueen käyttäjämäärän lisääntyessä ja käyttäjäprofiilin monipuolistuessa kasvaa erilaisten palvelujen kysyntä ja vähitellen myös tarjonta, mikäli kampukselta löytyy sille sopivia tiloja. Tällainen kehityskulku lieventää opiskelijoiden kokemusta kampuksesta työpaikkana ja lisää sattumanvaraisia kohtaamisia ja siten mahdollisuuksia informaaliin oppimiseen.

Erityisen tärkeää on luoda kampukselle tiloja, joissa ihmiset voivat tavata toisiaan vapaamuotoisesti ja joiden olot ovat suotuisat keskusteluille ja yhteistoiminnalle. Muun muassa kioskit, kahvilat ja ravintolat terasseineen, pienet myymälät, kerhohuoneistot ja puistoalueiden istuskelupaikat tarjoavat tällaisia oloja. Julkiset tilat, kuten sisäpihat, atriumit ja aukiot, ja liikennerakenteet, kuten polut ja portaat, voivat nekin edistää keskustelua kampuksella (Burlage \& Brase 1997). Eivät pelkästään opetustilat vaan koko kampusalue on ymmärrettävä oppimisen paikaksi (Brown \& Long 2006, 9.1). Hurjimmissa ideoissa väläytellään jopa koko kampuksen muuttamista interaktiiviseksi oppimislaitteeksi (Oblinger 2005, 16).

\section{VIHERALUEET JA KAMPUKSELLA VIIHTYMINEN}

Aiemmista ympäristöpsykologian ja ihmismaantieteen tutkimuksista tiedetään, että puistomaiset viheralueet ovat kampuksella viihtymiselle ja oleskelulle olennaisia. Liverpool Hope -yliopistoa koskevassa tutkimuksessa todettiin, että etenkin naiset ja perustutkinto-opiskelijat käyttivät viheralueita sosiaalisiin tarkoituksiin, kuten tapaamisiin, odotteluun ja ystävien kanssa jutusteluun. Erityisesti rakennusten lähellä olevat viheralueet olivat vilkkaassa käytössä, ja opiskelijat kertoivat niiden olevan heidän mielipaikkojansa kampuksella. Perusteluiksi he esittivät sekä esteettisiä arviointeja, kuten 'nätti', 'houkutteleva' ja 'näyttää hyvältä', että toiminnallisia syitä, kuten 'rentouttava', 'paikka syömiselle ja juomiselle' ja 'sosiaalinen'. Lähes jokainen opiskelija (97\%) piti tutkimuksen mukaan kampuksen viheralueita erittäin tärkeinä tai tärkeinä yliopiston imagolle. Merkille pantavaa on, että kampuksen vieressä sijaitsevia luontoalueita ei yksikään 205 haastatellusta opiskelijasta nimennyt mielipaikakseen. (Speake, Edmondson \& Nawaz 2013, 24-26.)

Suomessa tehdyssä mielipaikkatutkimuksessa (Korpela \& Hartig 1996) tuli esiin, että Tampereen yliopiston opiskelijat $(\mathrm{N}=78)$ valitsivat mielipaikakseen kodin lisäksi yleensä paikan viher- tai vesistöalueella. Epämieluisat paikat olivat tavallisesti liikennealueita tai paikkoja, joissa oli ihmisiä ruuhkaksi asti. Opiskelijoiden ikä vaihteli 19 vuodesta 46 vuoteen, ja naisia oli tutkittavissa jonkin verran enemmän kuin miehiä. Tutkimus oli osa Yhdysvalloissa, Ruotsissa ja Suomessa tehtyä ympäristöpsykologian alan tutkimussarjaa (Hartig ym. 1997) Mukana oli osallistujamaista 363 yliopisto-opiskelijaa, joista 210 oli naisia.

Tutkimussarja osoitti, että yliopistokampuksella ja sen lähiympäristössä puistomaiset alueet ja vihreys olivat yhteydessä ympäristön havaitun elvyttävyyden kaikkiin osakokemuksiin, joita ovat lumoutuminen, arjesta irtautuminen, koherenssi ja itselle sopivuus. Tuloksissa vakioitiin muun muassa opiskelijoiden kansalaisuus, se kuinka hyvin paikka tunnettiin sekä vuodenaika ja tapa, jolla paikkaan tutustuttiin.

Tekemämme haastattelut tukevat käsitystä siitä, että opiskelijat kokevat viheralueet erityisen houkutteleviksi. Kysyttäessä, miten viihtyisinä haastatellut pitivät kampusalueen ulkotiloja ja mikä niistä teki viihtyisiä, saatiin muun muassa seuraavia vastauksia: 
"Tää on hyvin viihtyisä ja tos on kiva ku tos on meri ja kumminki vihreätä, tosi hyvä ja kompakti paikka, ei oo hajoitettu mitenkään pitkälle matkalle tätä, vaan luentosalit ja opiskelut löytyy tästä." (H8, Vaasa, mies, noin 30 vuotta)

"[Kampus on] mun mielestä tosi mukava, täällä on rento ilmapiiri ja sitte ehkä ainakin mulle itselle tulee rennompi olo et täällä on niin paljon luontoa tässä kampuksen keskellä, niin paljon puita ja kaikkea vihreätä ja tossa takana tuo mäki jolla on sitte ihan kunnon metsäkin ja joku lenkkipolkukin.” (H13, Jyväskylä, mies noin 30 vuotta)

"--] Muuten ihan toimiva, varsinkin tossa päätalon katolla kun on toi viheralue, niin musta se on ihan hauska yksityiskohta. Toimiva."

(H18, Tampere, mies, noin 30 vuotta)

"En miä ole ainakaan vielä löytänyt sellaista ajanviettoon tarkoitettua [ulkotilaa], ehkä noissa ravintoloissa on pöytiä ulkona missä istuskeltiin viime syksynä. Mut vois olla kiva, et olis semmoisia puistomaisia alueita missä voisi viettää aikaa. Muuten ne on ihan kivat." (H22, Joensuu, nainen, noin 20 vuotta)

Opiskelijoiden myönteinen suhtautuminen kampusten viheralueisiin ja näiden käyttö sosiaalisiin toimintoihin viittaa vahvasti siihen, että ne ovat olennaisia yliopistokampusten elävöittämisessä ja viihtyisien ympäristöjen kehittämisessä, mikä taas edistää kampusten ulkotilojen viikonloppu- ja iltakäyttöä. Viheralueet luovat parhaimmillaan sopivan rauhalliset olot keskustelulle ja samalla puitteet harrastustoiminnoille, jotka ovat tärkeitä informaalia oppimista edistävässä ympäristössä. Suomen kampuksia suunnitellessa pitää kiinnittää erityistä huomiota viheralueiden käytettävyyteen talvisin.

\section{POHDINTA}

Urbanisoituva yliopistokampus on monin tavoin sidoksissa sitä ympäröivään kaupunkiin. Urbaaniuteen kuuluvat yhdyskuntarakenteen tiiviys ja toiminnallinen monimuotoisuus, joiden voi olettaa kasvavan uusien käyttäjäryhmien ja toimintojen myötä. Näiden houkuttelu alueelle ja kampusalueen rakenteen samanaikainen tiivistäminen parantavat informaalin oppimisen edellytyksiä lisäämällä kohtaamisia ja vuorovaikutustilanteita. Niitä näyttää lisäävän myös puistomaisten viheralueiden viihtyisyyden ja käyttökelpoisuuden parantaminen.

Empiirisessä taustatutkimuksessamme huomasimme, että kampuksia käytettiin varsin vähän työaikojen ulkopuolella. Lisäksi monet mahdollisuudet kampusten toimintojen ja ulkotilojen monipuolistamisessa olivat hyödyntämättä, mutta mukana kampusstrategioissa.

Haastatteluaineistomme osoittaa, että haastateltavien kokemustiedon käyttäminen kampusalueiden suunnittelun pohjana voi olla ongelmallista toisistaan poikkeavien ja päinvastaistenkin näkemysten vuoksi. Saimme kuitenkin selviä viitteitä monien opiskelijoiden haluttomuudesta asua kampusalueella, he kokevat ikään kuin käyvänsä töissä yliopistolla. Asiaa on syytä tulevaisuudessa tutkia vielä tarkemmin.

Sen sijaan, että rakennetaan kampusalueille asuntoja yliopisto-opiskelijoille tai yliopiston työntekijöille, voi olla hedelmällistä tiivistää alueita rakentamalla asuntoja ja palveluja muillekin. Näin monipuolistetaan kampuksen käyttötapoja ja tuodaan alueelle lisää käyttäjiä, jotka puolestaan mahdollistavat uusien palvelujen tuottamisen. Uusien asukkaiden myötä syntyy uusia tapoja viettää vapaa-aikaa, mikä parantaa kampuksen elinvoimaisuutta iltaisin, viikonloppuisin ja loma-aikoina. Keskustan reuna-alueiden urbanisoituvilla yliopistokampuksilla artikkelissa esittämämme elävöittämistoimet ovat varsin realistisia, kiitos kampuksen sijainnin, ympäröivän kaupunkialueen väkiluvun kasvun ja urbanisoitumisprosessin, jotka tarjoavat resursseja ja mahdollisuuksia suuriinkin muutoksiin.

Kaupunkimainen tiiviys ja monimuotoisuus sekä urbaanit puistot sivuavat kaikki käveltävyyden teemaa, joka sisältää monimuotoisia aluesuunnittelutason asioita maankäytön monipuolistamisesta mielenkiintoisten tilojen rakentamiseen ja puiden istuttamiseen. Käveltävyyteen liitettyjä laatu-ulottuvuuksia voidaan toteuttaa suhteellisen tiiviissä kaupunkirakenteessa, jossa asukasmäärä on riittävä (Kuoppa 2016, 34), toisin sanoen urbaanissa ympäristössä. Kävelemisen 
selkeys, vaivattomuus ja helppous kampusalueilla, toimintojen läheisyys ja moninaisuus sekä viheralueiden istuskelupaikat ja rauhoittavuus edistävät satunnaisia kohtaamisia. Ne ovat tärkeitä paitsi informaalin oppimisen mahdollisuuksien edistämiselle myös kampusidentiteetille ja siellä toimivien ihmisten yhteistoiminnalle. Käveltävyyden parantaminen lisää kampusalueen viihtyisyyttä ja helpottaa sen integraatiota ympäröivään kaupunkirakenteeseen.

Kiinnostavia informaalin oppimisen mahdollisuuksia saattaa sisältyä kampusalueiden palvelujen tuottamisen ja käyttämisen digitalisoitumiseen, jonka myötä on muodostumassa monenlaisia virtuaalista ja fyysistä ympäristöä sekoittavia älykkään kaupunkielämän muotoja. Kun niitä käytetään luovasti, voi olla mahdollista viedä eteenpäin yliopistokampusten urbanisoitumista ja luoda uusia tapoja informaalille oppimiselle. Digitalisaation tarjoamia mahdollisuuksia yliopistokampuksille emme kuitenkaan suoraan tarkastelleet.

Urbanisoituvan yliopistokampuksen elävöittäminen ja sen myötä informaalin oppimisen edellytysten parantaminen vaatii kampuksen toimintojen ja ulkotilojen suunnittelulta näkökulmaa, jossa erillisen ja itsenäisen yliopistokampuksen sijaan tavoitellaan ja rakennetaan monimuotoista, tiivistä, vuorovaikutteista ja innovatiivista yliopistokaupunkia.

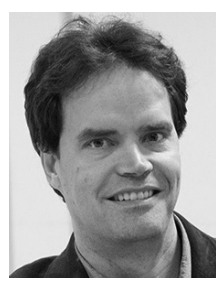

JUHO RAJANIEMI

arkkitehti, TkT,

yhdyskuntasuunnittelun

professori

arkkitehtuurin laboratorio

Tampereen teknillinen yliopisto

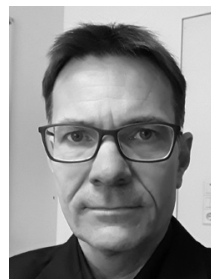

JOUNI HÄKLI

HTM, FT,

aluetieteen professori

Johtamiskorkeakoulu

Tampereen yliopisto

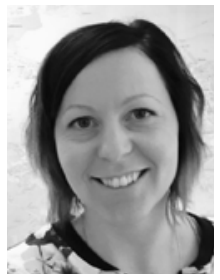

KATARIINA RAUHALA

HTM, kiinteistökehitys-

koordinaattori

Tampereen kaupunki

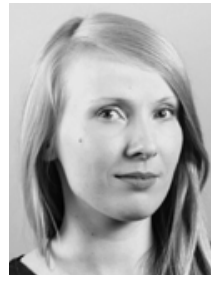

HEIDI SUMKIN

arkkitehti, suunnittelija

Ramboll Finland Oy

Tutkimustamme on rahoittanut Suomen Yliopistokiinteistöt

Oy. Ensimmäisen artikkeliluonnoksen kommentoinnista

kiitämme dosentti Suvi Nenosta ja dosentti Olli Niemeä.

\section{LÄHTEET}

Aaltocre.fi (2016). http://aaltocre.fi/en/otaniemi-a-smallcity-of-its-own/otaniemi-operational-environment (14.6.2017).

Brown, M. \& Long, P. (2006). Trends in Learning Space Design. Teoksessa Oblinger, D. G. (toim.) Learning Spaces. EDUCAUSE, 9.1-9.11.

Burlage, J. \& Brase W. (1997). Campus Architecture That Shapes Behavior. Teoksessa Keller, G. (toim.):
The Best of Planning for Higher Education: An Anthology of Articles from the Premier Journal in Higher Education Planning. Ann Arbor, Michigan: Society for College and University Planning, 114-119.

Callanan, M., Cervantes, C. \& Loomis, M. (2011). Informal learning. Wiley Interdisciplinary Reviews: Cognitive Science 2 (6), 646-655. 
Elliott, P. G. (1994). The Urban Campus: Educating the New Majority for the New Century. Phoenix: The Oryx Press.

HE 7/2009. Hallituksen esitys Eduskunnalle yliopistolaiksi ja siihen liittyviksi laeiksi.

Hartig, G., Korpela, K., Evans, G. W. \& Gärling, T. (1997). A Measure of Restorative Quality in Environments. Scandinavian Housing \& Planning Research 14, 175-194.

Heijer, A. den (2011). Managing the University Campus. Information to Support Real Estate Decisions. Delft: Eburon Academic Publishers.

Hyökki, S., Kaikonen, H. \& Nenonen, S. (2015). Mun, sun, meitin kampus - Lahden kampuskehitys. Teoksessa Nenonen, S. ym. Oppiva kampus. How to co-create campus? Tampere: Suomen Yliopistokiinteistöt Oy, 108-121.

Ibrahim, N. \& Fadzil, N. H. (2013). Informal Setting for Learning on Campus: Usage and preference. Procedia - Social and Behavioral Sciences 105, 344-351.

Ilmonen, M. (2010). Mitä on urbaani? Urbaanin määrittelyjä tarkastelussa. Teoksessa Norvasuo, M. (toim.): Asutaan urbaanisti!: Laadukkaaseen kaupunkiasumiseen yhteisellä kehittelyllä. Espoo: Aalto ARTS Books, 19-28.

Korpela, K. \& Hartig, T. (1996). Restorative qualities of favorite places. Journal of Environmental Psychology 16, 221-233.

Kumpulainen, K. ym. (2010). Oppimisen sillat. Kohti osallistavia oppimisympäristöjä. Helsinki: CICERO Learning, Helsingin yliopisto.

Kuoppa, J. (2016). Kävelyn lupaukset kaupungissa: Kolme tapausta kävelijöiden arjesta ja kokemuksista sekä kaupunkisuunnittelusta. Tampere: Tampereen yliopisto.

Livingstone, D.W. (2001). Adults' Informal Learning: Definitions, Findings, Gaps and Future Research. WALL Working Paper 21. Toronto: Centre for the Study of Education and Work. http://citeseerx.ist.psu. edu/viewdoc/download?doi=10.1.1.585.3940\&rep $=r$ ep1\&type=pdf (27.10.2017).

Marsick, V. J. \& Watkins, K. E. (2001). Informal and Incidental Learning. Teoksessa New Directions for Adult and Continuing Education 89, 25-34.

McNamara Horvat, E. \& Shaw, K. M. (1999). Redefining Campus: Urban Universities and the Idea of Place. New Direction for Higher Education 105, 101-107.

Oblinger, D. (2005, alkuperäisteos 2004). Leading the Transition from Classrooms to Learning Spaces. Educause Quarterly 2005 (1), 14-18.

Paasi, A. (1986). Neljä maakuntaa: maantieteellinen tutkimus aluetietoisuuden kehityksestä. Joensuu: Joensuun yliopiston yhteiskuntatieteellisiä julkaisuja, 8.
Poutanen, J. (2015). What makes a Place? Claiming spaces for informal and social learning. Teoksessa Nenonen, S. ym. Oppiva kampus. How to co-create campus? Tampere: Suomen Yliopistokiinteistöt Oy, 360-377.

Poutanen, J., Peltoniemi, S. \& Pihlajarinne, N. (2015). Uudet ratkaisumallit muuttavat kampuksien ilmettä. Teoksessa Nenonen, S. ym. Oppiva kampus. How to co-create campus? Tampere: Suomen Yliopistokiinteistöt Oy, 72-93.

Rytkönen, E. (2016). University Campus Management Dynamics in Spatial Transformation: Systemic facilitation of interdisciplinary learning communities. Espoo: Aalto-yliopisto, Doctoral Dissertations 52/2016.

Schugurensky, D. (2000). The forms of informal learning: towards a conceptualization of the field. WALL Working Paper 19. Toronto: Ontario Institute for Studies in Education of the University of Toronto. https://tspace.library.utoronto.ca/bitstream/1807/2733 /2/19formsofinformal.pdf (14.6.2017).

Sennett, R. (1977). The Fall of Public Man. New York \& Lontoo: W. W. Norton \& Company Ltd.

Southworth, M. (2005). Designing the Walkable City. Journal of Urban Planning and Development 131 (4), 245-257.

Speake, J., Edmondson, S. \& Nawaz, H. (2013). Everyday encounters with nature: students' perceptions and use of university campus green spaces. Journal of Studies and Research in Human Geography 7 (1), 21-31.

Speck, J. (2012). Walkable City. How Downtown Can Save America, One Step at a Time. New York: North Point Press.

Sykoy.fi (2014). http://sykoy.fi/palvelumme/kampuskehitys (14.6.2017).

Temple, P. (2008). Learning spaces in higher education: an under-researched topic. London Review of Education 6 (3), 229-241.

Tirronen, J. \& Kivistö, J. (2009). Uusi hyödyn aikakausi ja yliopiston kolmas tie. Teoksessa Aarrevaara, T. \& Saarinen, T. (toim.). Kilvoittelusta kilpailuun. Artikkelikokoelma Korkeakoulututkimuksen juhlasymposiumista 25.-26.8.2008. Jyväskylä: Jyväskylän yliopistopaino, 57-82.

VNA 322/2016. Valtioneuvoston asetus yliopistoista annetun valtioneuvoston asetuksen 5. ja 7. §:n muuttamisesta.

Vuorinen, J. (2011). Muutoksen kampukset. Helsinki: Museovirasto.

West, G. (2017). Skaala. Elämän ja kuoleman universaalit lait eliöissä, suurkaupungeissa ja yhtiöissä. Helsinki: Terra Cognita. 